\title{
THE FUTURE OF MARKET \\ SEGMENTATION AND RELATIONSHIP MARKETING IN THE TOURISM AND HOSPITALITY SECTORS
}

\author{
Susan Horner*
}

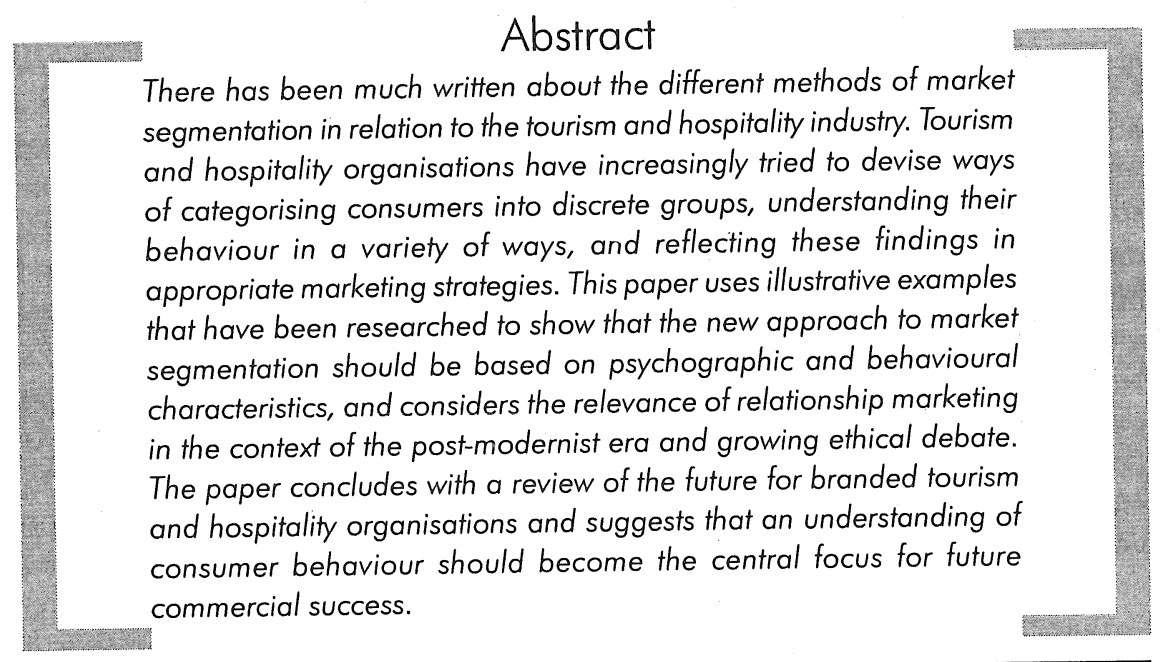

* Principal Lecturer, School of Sport and Leisure Management, Sheffield Hallam University, Pond Street, Sheffield, S1 1WB, UK, e-mail s.horner@shu.ac.uk 
Key words: Tourism and hospitality organisations, market segmentation, marketing strategy, consumer behaviour, relationship marketing, post-modernism, branding, ethical marketing.

\section{Introduction}

Tourism and hospitality organisations have embraced the concept of market segmentation in an attempt to categorise consumers into discrete groups to enable them to understand their behaviour and reflect this knowledge in appropriate marketing strategies (Swarbrooke and Horner, 1999). All of this marketing activity has been based on the premise that we exist in an individualistic and self-motivated culture and seek high profile brands to satiate our consumerist desires. It has also tended to use traditional methods of market segmentation such as demographic, socio-economic and geographic. Increased emphasis has also been placed on building relationships with consumers (Grönroos, 1994). It could be argued that activities have largely been examples of bribery and corruption rather than sophisticated methods of building up long term relationships (Lindgreen, 2001) to form groups of people with a shared understanding (Cova and Cova, 2002). These issues will now be debated with reference to illustrative examples that have been researched by the author and conclusions drawn for branded tourism and hospitality organisations.

\section{Major Flaws with Market Segmentation}

One of the key techniques in marketing that the tourism and hospitality industry has had to embrace is the concept of market segmentation because it should allow practitioners to effectively target selected groups of the population with specially designed accommodation, food and beverage, and tourism products and services. Successful use of market segmentation allows the tourism and hospitality provider to identify target groups of consumers who have similar needs and wants and then design marketing mixes to meet their collective needs (Dibb, Simkin, Pride and Ferrell, 2001). There are five main techniques that have been used traditionally by hospitality providers which are demographic, socio-economic, geographic, psychographic and behavioural. The tourism and hospitality industry has particularly focussed on the first three methods of market segmentation because it is easier to collect and interpret market research data using these methods. The use of psychographic and behavioural methods of market segmentation requires much more qualitative methods of marketing research and individual targeting of consumers (Swarbrooke and Horner, 1999). The use of the family life cycle technique that forms a part of the demographic method 
has been particularly effective for hospitality and tourism providers. A large hotel chain such as Accor, for example markets products and services that have been branded on an international basis to appeal to single people, young families, older couples, and single retired consumers (Swarbrooke and Horner, 2001).

It can be argued that the psychographic and behavioural methods of segmentation that concentrate on the lifestyle, personality and values of the consumer are more useful to the tourism and hospitality marketer. This is because knowledge about the benefits sought, attitudes to the products and services, and user status are more useful to consider because of the power that this combined understanding will provide for the creation of effective marketing mixes. This multi-variable approach to market segmentation will allow better positioning of products and targeting of the marketing mix.

At the foundation of market segmentation is the desire to understand consumer behaviour. New issues that have emerged in the literature recently suggest that there are new challenges for tourism and hospitality organisations in the future. Consumers now like to be seen as travellers, rather than tourists, they look for authentic and new experiences, and have increased desires to learn (Sharpley, 1994; Urry, 1995; Horner and Swarbrooke, 1996).

All of these new desires can be attributed to postmodernism which it is suggested is having a compelling force on all society today (Gitlin, 1989; Habermas, 1983; Hutcheon, 1988; Jameson, 1992). The effects of postmodernism on the future of marketing has been debated to a limited extent by a few marketing scholars (Ogilvy, 1990; Sherry, 1991; van Raaii, 1993; Venkatesh, 1992; Firat, 1997; Firat and Shultz, 1997). It has been suggested that existing methods of market segmentation are inappropriate for organisations because of the fragmented and fluid spectacles, images and lives that consumers exist within the postmodern world (Firat and Shultz, 1997). They suggested that marketing will have to become very flexible and concentrate on continual image generation rather than branding and seek to empower consumers in fluid markets. They gave examples of hospitality organisations that have started to address these issues in their marketing strategies such as the theming of hotels in the Las Vegas concept and the Electronic Café International experiment (Galloway and Rabinowitz, 1989) where consumers can experiment with new communication and information technologies (Firat and Shultz, 1997). They finished their paper by suggesting that organisations will benefit by gaining "a better understanding of the underlying macro social forces and micro human behaviour associated with postmodernism" (Firat and Shultz, 1997). A parallel concept that has developed over the last two decades has been that of relationship marketing 
that has tried to cope with an increasingly fragmented market and treat consumers as individuals even in mass-market situations. This concept will now be reviewed in relation to tourism and hospitality organisations.

\section{The Concept of Relationship Marketing}

The concept of relationship marketing has been developing over the last two decades, and academics have been trying to ground the subject in the literature, at the same time as the practitioners have been developing ways of communicating directly with consumers on a one to one basis. Academics have given different definitions of what relationship marketing actually means. Lindgreen (2001) gave an excellent review of the literature on the topic. He quoted the first definition of relationship marketing that was developed in relation to service marketing that is useful for hospitality organisations:

Relationship marketing is attracting, maintaining and - in multi-service organizations enhancing customer relationships. Servicing and selling existing customers is viewed to be just as important to long term marketing success as acquiring new customers (Berry, 1983, p 25).

He also quoted one of the most famous definitions of relationship marketing that reflects the long-term relationship that has to be developed with consumers and which originated from the Nordic view of marketing:

(Relationship) marketing is to establish, maintain, and enhance relationships with customers and other partners, at a profit, so that the objectives of the parties involved are met. This is achieved by mutual exchange and fulfilment of promises" (Grönroos, 1994, p 355).

It is important to note in this definition that the concept of relationship marketing refers to the development of long-term contact, rather than simply a short-term sales promotion in the form of a bribe. For the tourism and hospitality industry relationship marketing techniques have been developed on the basis of a number of objectives. These include customer satisfaction and delight (Oliver et al 1997), customer retention (Buchanan and Gillies, 1990) and customer loyalty (Palmer, 1994).

The practical ways that have been used to achieve these objectives have included the use of direct marketing techniques such as hotel loyalty schemes. The use of database marketing techniques has also tried to improve long term contact (Swarbrooke and Horner, 2001).The development of relationship marketing programmes is however still in the early stages. The measurement of the long- 
term benefits of the programmes is still to be quantified (Lindgreen, 2001). It has also been suggested that no guidelines exist to guarantee the effective implementation of a relationship programme and confusion often occurs in their development (Grande, 1996; Pinto, 1997; Palmer, 1998).

Despite the academic debates about the topic, relationship marketing seeks to develop long-term relationships with consumers, and to create involvement and product loyalty by developing a permanent bond between consumers and organisations, and between consumers themselves. There are ethical issues looming here for the hospitality industry. There are already signs that consumers are beginning to reject personal contact from large organisations, and ethical questions have already been raised about the business practices of large organisations in relation to direct contact with consumers (Takala and Uusitalo, 1996). Enlightened commentators have suggested that organisations should adopt an ethical stance on the development of relationship marketing programmes on the basis of keeping promises and truth telling, equal treatment of customers, and commitment and communication (Takala and Uusitalo, 1996). Whether this is feasible in the highly competitive world of the tourism and hospitality industry remains to be seen. What is clear is that postmodern consumers may well reject personal contact from large organisations unless it offers distinct benefits and powerful images.

The paper so far has shown how tourism and hospitality organisations should try to adopt appropriate methods of market segmentation, and constantly research consumer behaviour. It has also questioned the definition and usefulness of relationship marketing techniques in the tourism and hospitality sector.

\section{The Research Method}

The research method that has been adopted for this paper is the collection of small illustrative examples of hospitality organisations drawn from primary and secondary research. The examples have been chosen because they are considered to offer insights into phenomena (Herriot and Firestone, 1983; Denzin and Lincoln, 1984). They are also considered to be cases of best practice in relation to market segmentation and relationship marketing within the tourism and hospitality sector, and can therefore offer some answers to the complex set of issues raised in relation to marketing practices.

Training and experience have been used to provide the illustrative examples but it must be remembered, however that the purpose was not to represent the world. The use of the commercial examples is to enable the author to extend experience, 
and not to form any particular theories (Denzin and Lincoln, 1984). The illustrative examples are used to illustrate 'a point, condition, a category, something important for instruction and will be useful for teaching purposes' (Kennedy, 1979).

The commercial examples have been chosen to focus on market segments rather than organisations, although organisations will be used to illustrate the points made. The rationale for this type of approach is so that the focus will be on the consumer, rather than the organisation, so that consumer behaviour and marketing response can be explored in more depth. The illustrative examples have been drawn from primary and secondary research that has been ongoing between 1995 and 2005.

\section{Targeting the Post-modern Consumer}

This section of the paper considers different categories of the post-modern consumer, and uses illustrative examples of organisations that are considered to have demonstrated models of particularly good practice in relation to market segmentation strategies and relationship marketing.

\section{The Health Seeker}

The Health Seeker as a mass-market segment is one that has emerged in the postmodern era. The health seeker constantly looks for new experiences that will enrich their image of their bodily appearance both on the inside and the outside. They have a determined set of values in relation to diet, health, and activities. This segment has been well identified by using psychographic and behavioural methods of market segmentation. Consumers in this segment originally came from the younger age groups, but there are signs that the segment is now growing up and older people are now showing a growing interest in this phenomenon (Swarbrooke and Horner, 1999).

The development of the health spa market is the best example of exploitation of this market segment by the hospitality sector. Spas, like the one in Bath are being redeveloped to answer the growing demand for spa treatment in Britain. Spa hotels such as The Academy in Harrogate, the Athenaeum Hotel, and the Roundelwood Health Spa in Perth have already communicated directly with consumers via powerful internet images (Guardian, 1999). There are even designer hotels that focus on up market spa treatments - K West is one of these in London's Shepherd Bush and seeks to attract image conscious consumers largely from the design and media industries. 
One of the best examples of a health spa that relies heavily on repeat custom from this market segment is Ragdale Hall in Leicestershire UK. This is a privately owned hotel and health spa complex that has gained a national reputation for the quality of provision. It has constantly upgraded the facilities on offer, and always tries to introduce new facilities and treatments, as they become available. Examples of these are provision for underwater circuit training, new massage techniques, and holistic therapies. The organisation also puts great emphasis on the quality of their food and accommodation provision. The organisation has developed a very loyal group of consumers and over $60 \%$ of the business generated is repeat business. This has been achieved by creating the right image, constant communication with customers with a newsletter and up to date offers, and creating an informal club like atmosphere on the site (Swarbrooke and Horner, 1999). The organisation continuas to improve their customer loyalty programmes and offer an improved range of hospitality and beauty services on the basis of customer feedback (Ragdale Hall, 2005).

This illustrative example has shown how a new market segment has emerged in recent years and how particular hospitality organisations have chosen to focus their marketing activities in this direction. The Health Seeker is a person who has very well developed images of their body and constantly seeks new experiences to satisfy their desires. The UK version of this person is one that is focussed very much on beauty rather than their French equivalent who is much more focussed on health benefits. The development of relationships is important because repeat purchase is a very critical part of the market. The development of tribal associations and belonging in a club like environment is a very important part of the service offering (Cova and Cova, 2002).

\section{The Environmentalist}

This market segment emerged much earlier in certain parts of the world than others, and has become mainstream rather than niche in certain areas such as Germany and Holland. The emergence of consumers who were interested in the environmental initiatives of organisations in general happened very early in Germany and the Scandinavian areas of Europe for a variety of complex reasons including the state of the economy, political movement, and media influence (Horner and Swarbrooke, 1996). The development of the consumer that is interested in environmental issues has been attributed to the postmodern era and it has been argued that the ultimate development of this trend will be consumers who will reject global brands entirely and return to locally produced products and services. Whether this will happen in our highly developed economy is worthy of debate. 
Tourism and hospitality organisations have reacted in a variety of ways to suit the needs of this market segment. Initiatives have also been fuelled by supply side factors such as legislative changes and consumer movements. It is interesting to consider the environmental initiatives of two hospitality organisations that have their historic roots outside the UK - TUI the German tour operator and Center Parcs the holiday village operator that had its beginnings in Holland.

TUI the German based tour operator (Touristik Union International), is Europe's largest tour operator and has been heavily involved in environmental initiatives since it appointed an Executive Director in 1990 to head up its conservation and environmental activities. The company claims that the value of environmental initiatives in the hospitality industry is because holiday regions and resort hotels cannot remain successful in the long term without clean beaches, clean water, and unspoiled landscape. They have argued that environmental action is an issue of enlightened self interest, and a way to target a growing number of consumers who are interested in 'eco-labelling' and 'eco-auditing'. These initiatives can be largely attributed to the high levels of concern with environmental issues amongst German consumers in the early days (Horner and Swarbrooke,

It is ironic that it is the environmental initiatives of TUI that have forced many of their suppliers such as hotels and transport companies to adopt simple measures to help reduce the negative environmental impact of the total operation. Checklists are used to audit the hotels, clubs and holiday apartments that are contracted by the group. TUl also influences destination regions by encouraging the development of water treatment plants, alternative regenerative energy sources, intelligent beach cleaning technology, and sustainable land use.

TUI have more recently developed relationships with consumers by regular market research, use of databases, and communication of all initiatives including their environmental strategy. Their environmental initiatives have become part of their high volume package holiday business and consumers expect these now as the norm in Germany. The business is busy expanding in Europe and indications suggest that this approach will become a central part of the strategy in all new markets in the future.

Center Parcs was originally developed for the Dutch market and has since spread across the whole of Europe. It currently has operations in Holland, Belgium, France, England and Germany. The company is now a world leader in the shortbreak market and constantly adds new features to the holiday sites. A recent addition to the facilities has been the introduction of spas deliberately targeted 
at their adult consumers to allow them to retreat from their children for a short time during their break (Center Parcs, 2005).

Center Parcs was launched in the UK to attract a very particular type of customer:

Center Parcs offers a new upmarket holiday experience where, for 52 weeks of the year, guests can get away from the hassle of everyday life to enjoy a special environment with people who share the same values and want the same thing out of a holiday break in terms of facilities, service etc (Horner and Swarbrooke, 1996).

The original target group in Holland was families who had an interest in the environment, were generally in high-pressured jobs, and who had higher than average incomes. The UK based consumer is a family who has higher than average income and is attracted to the carefree environment and the location of the villages in forest areas where the environment plays a big part.

It has been seen from these illustrative examples that organisations have developed successful business by the targeting of consumers using psychographic and behavioural market segmentation techniques. They have also relied on direct selling using brochures, telephone sales, and internet sales to develop a comprehensive database to allow the companies to encourage high levels of repeat purchase. New tourism and hospitality products and services have been added to encourage customers to return to the companies and both have strived to promote mutual exchanges and fulfil promises in enhanced relationships (Grönroos, 1994).

\section{The Techno-freak}

This market segment is generally young but has personal belief in the use of technology in life for functional reasons or for pure entertainment. The market segment is growing on an international basis as technology develops and access widens. This is the person who has the latest mobile phone with all the technological developments such as photo-messaging, internet links and game opportunities. They have regular access to the internet, satellite television stations and game machines, and are very much tuned in to the latest media events and trends. The values that they aspire to are those of extending the possibilities of communication and using cutting edge technology to their best advantage at home and at work. This segment includes business people as well as youngsters in their teenage years.

One of the best examples of hospitality organisations that have targeted this market segment is the growing number of internet cafés that have developed on a world-wide basis. It is estimated that there are now 3,000 cyber cafés in 143 
countries worldwide although it appears to be a largely fragmented industry with no major worldwide players (Steeves, 2002).

An internet café guide of the world has just been published to allow this market segment to identify the location of the nearest cyber café in any city of the world. One statement that introduces this book explores the insecurity that is part of the mind-set of this market segment:

'Stay in close contact with home. Understand that loved ones are nervous. You can call or go to a cyber café and send e-mails' (Rick Steeves, 2002)

Major hotel chains such as Marriott are including game machines and internet technology in their rooms to accommodate this market segment (Marriott, 2005). The advantage of technology in the field of relationship marketing is that it allows consumers to join together on an international basis to discuss both positive and negative experiences in relation to an organisation. This could allow subcultures to develop that could undermine organisational strategies. It could also be used positively to develop tribal associations on a global basis.

\section{The Style-guru}

This market segment can be attributed to the post-modern era. They are characterised by being cash rich, time poor and seeking out authentic products and services. They do not like logos but still have a secret desire for brands and like making fashion statements (Mintel, 2002). Design and fashionable products and services are a key part of the life of these individuals who tend to work in the cultural industries.

The tourism and hospitality industry has begun to target this market segment with the introduction of the boutique hotel. Boutique hotels were first developed by small operators but have more recently been developed by some of the larger hospitality chains such as the Le Méridien Hotel Group that is using the concept of the boutique hotel to transform the group. The essence of the boutique hotel is that it copies the ideas developed by boutique shops and offers a specialist niche offering which offen relies on a famous designer such as Philippe Starck or a particular type of styling such as feng shui. The hotel may be developed under a brand name such as Malmaison, but the branding approach is discrete and does not rely on a logo. Boutique hotels have been growing in both the US and UK markets and are predicted to grow much further in terms of market share in the hotel sector (Mintel, 2002).

lan Schrager Hotels (more recently Morgans hotel group) are currently developing the boutique concept in the US and the UK. They have based the hotels on 
simple concepts and have a very strong positioning statement 'Daring Imaginative and Provocative. A distinct point of view, cheap chic, conventional hotel philosophy turned on its head. One of a kind, lobby socializing, poetic and whimsical. A new paradigm. Disregard convention. Hotel as theatre. Magical and memorable. A visceral experience' (lan Schrager 2003). Ian Schrager is an American entrepreneur who saw the opportunity for hotels with a difference. The company currently operates eight hotels in the US and two hotels in the UK. The company has used various designers to help them to develop the special interiors of the hotels including Philippe Starck and Frank Gehry. The hotels have been met with great enthusiasm by the style media, such as Vogue, and Homes and Gardens. The company is actively pursuing possible opportunities in Asia (Mintel, 2002).

It is interesting that this new development is perhaps one of the best examples of the hospitality industry beginning to target the postmodern consumer. It does, however, have huge implications for the large branded hotel operators if this trend continues to grow and become a mainstream rather than a niche offering. This supports the views of Firat and Shultz (1997) that organisations need to gain 'a better understanding of the underlying macro social factors and micro human behaviour associated with postmodernism'.

\section{Meanings for Branded Tourism and Hospitality Organisations}

This paper has explored the concept of market segmentation and relationship marketing in the context of the tourism and hospitality sector. The illustrative examples have shown the importance of psychographic and behavioural methods of segmentation in the current competitive environment. It has cited examples of organisations that were the first to exploit emerging market segments, and develop successful long-term relationships with consumers with the use of appropriately designed relationship marketing techniques. The identification of emerging market segments has shown to be very important for tourism and hospitality organisations. The marketing campaigns of the organisations have also been affected by the new emphasis on relationship marketing. Personal contact with existing customers, coupled with long-term public relations campaigns appear to be much more effective than the mass marketing campaigns that organisations have traditionally engaged in. These personally focussed campaigns do need to be carefully designed, however, to avoid criticisms about possible invasion of privacy. One way of doing this seems to be to create feelings of belonging and membership of local, national or global 'clubs' that bring individuals together and enhances their life experiences. 
There are worries ahead however for the tourism and hospitality sector. The postmodern consumer may well require rapidly changing images and associations, rather than the powerful brand images that are created by hospitality organisations today. But will the predictions of academics on the ultimate outcome of cultural development ever come to fruition? What is clear is that tourism and hospitality organisations will have to develop the means to identify the increased fragmentation of society. They will also have to become more skilled at carrying out qualitative research to allow them to identify and react to changing consumer behaviour patterns and develop effective marketing campaigns that develop feelings of mutual trust and understanding. So is this the death of the brand or simply the death of the logo? It is likely that tourism and hospitality providers will have to forget standard offerings sold under brand logos in the next decade and beyond this. Their products and services will have to be increasingly designed to meet the demands of individual customers and there will have to be a transformation of approaches to the customer, brands, service delivery, distribution, and the use of technology. All of this will require new thinking and approaches for the tourism and hospitality operations manager.

\section{References}

1. Berry, L.L. (1983) 'Relationship marketing', in Berry, L.L., Shostack, G.L. and Upah, G.D. (Eds), Emerging Perspectives on Services Marketing, American Marketing Association, Chicago, IL, pp. 25-8.

2. Buchanan, R.W.T. and Gillies, C.S. (1990) 'Value managed relationships: the key to customer retention and profitability', European Management Journal, Vol. 8, No. 4, pp. 523-6.

3. Center Parcs (2005) at www.centerparcs.com

4. Cova, B. and Cova, V. (2002) 'Tribal Marketing', European Journal of Marketing, Vol. 36, No. $5 / 6$, pp. 595-620.

5. Denzin, N.K. and Lincoln, Y.S. (1984) (eds) Handbook of Qualitative Research, Sage Publications, Thousand Oaks California.

6. Dibb, S., Simkin, L., Pride, W.M., and Ferrell, O.C. (2001) Marketing: Concepts and Strategies, $4^{\text {th }}$ European edition, Houghton-Mifflin, London.

7. Firat, A.F. (1997) 'Postmodernism and the marketing organization', Journal of Organizational Change Management, Vol 10, No. 3, pp. 79-83.

8. Firat, F.A. and Shultz, C.J. (1997) 'From segmentation to fragmentation', European Journal of Marketing, Vol 31, No 3/4, pp. 183-207.

9. Galloway, K. and Rabinowitz S. (1989) 'Welcome to Electronic Café International', Cyberarts, pp. 255-63.

10. Gitlin, T. (1989) 'Postmodernism: roots and politics', in Angus, I. and Jhally, S. (eds), Cultural Politics in Contemporary America, Routledge, New York. 
11. Grande, I. (1996) Marketing de los Servicios, ISIC Editorial, Madrid.

12. Grönroos, C. (1994) 'Quo vadis marketing? Toward a relationship marketing paradigm', Journal of Marketing Management, Vol. 10, No. 5, pp. 347-60.

13. Guardian, (1999) Saturday July 17, 1999.

14. Habermas, J. (1983) 'Modernity - an incomplete project', in Foster, H. (ed), The Anti-Aesthetic Essays on Postmodern Culture, Bay Press, Port Townsend, WA.

15. Herriot, R.E., and Firestone, W.A. (1983) 'Multisite qualitative policy research: Optimizing description and generalizability. Educational researcher, Vol 12(2), pp 14-19.

16. Horner, S. and Swarbrooke, J. (1996). Marketing Tourism, Hospitality, and Leisure in Europe, International Thomson Business Press.

17. Hutcheon, L. (1988) A Poetics of Postmodernism: History, Theory, Fiction, Routledge, New York.

18. Ian Schrager hotels (2005) at hHtp://www.morganshotelgroup.com

19. Jameson, F. (1992) Postmodernism: Or the Cultural Logic of Late Capitalism, Duke University Press, Durham, NC.

20. Kennedy, M.M. (1979) 'Generalizing from single case studies', Evaluation Quarterly, Vol 3, pp. 661-678.

21. Lindgreen, A. (2001) 'A framework for studying relationship marketing dyads', Qualitative Marketing Research: An International Journal, Vol 4, No 2, pp. 75-87.

22. Marriott hotels (2003) at www.marriott.com

23. Mintel (2002) 'Boutique Hotels' Travel and Tourism Analyst, April, 2002.

24. Ogilvy, J. (1990), 'This postmodern business', Marketing and Research Today, Vol 18 No 1, pp 4-20.

25. Oliver, R.L., Rust, R.T. and Varki, S. (1997), 'The commitment-trust theory of relationship marketing', Journal of Marketing, Vol. 58, No. 3, pp 20-38.

26. Palmer, A. (1994) 'Relationship marketing back to basics', Journal of Marketing Management, Vol. 10, No. 7, pp. 571-80.

27. Palmer, A. (1998) Principles of Service Marketing, $2^{\text {nd }}$ edition, McGraw Hill, London.

28. Pinto, S.K. (1997) 'Marketing de relación o la transformación de la función de marketing', Harvard Deusto Business Review, pp. 32-40.

29. Van Raaii, W.F. (1993) 'Postmodern consumption', Journal of Economic Psychology, Vol 14, pp 541-63.

30. Ragdale Hall (2005) at http://www.ragdalehall.co.uk

31. Sharpley, R. (1994) Tourism, Tourists and Society, Elm, Huntingdon.

32. Sherry, J.F. Jr (1991) 'Postmodern alternatives: the interpretative turn in consumer research', in Kassariian, H. and Robertson, T. (Eds), Handbook of Consumer Theory and Research, PrenticeHall, Englewood Cliffs, NJ. 
33. Steeves, R. (2002) quoted on www.netcafeguide.com

34. Swarbrooke, J and Horner, S. (1999) Consumer Behaviour in Tourism. Butterworth Heinemann, Oxford.

35. Swarbrooke, J. and Horner, S. (2001) Business Travel and Tourism. Butterworth Heinemann, Oxford.

36. Takala, T. and Uusitalo, O. (1996) 'An alternative view of relationship marketing: a framework for ethical analysis', European Journal of Marketing, Vol 30, No. 2, pp. 45-60.

37. Urry, J. (1995) Consuming Places, Routledge, London.

38. Venkatesh, A. (1992) 'Postmodern consumer culture and society of the spectacle' in Sherry, J.F. Jr and Sternthal, B. (eds), Advances in Consumer Research XIX, Association for Consumer Research, New York. 